\title{
PENERAPAN MODEL PROBLEM BASED LEARNING (PBL) PADA MATA PEMBELAJARAN COREL DRAW UNTUK MENINGKATKAN HASIL BELAJAR DI RANAH PSIKOMOTOR
}

\author{
I Putu Suarbawa \\ SMK Negeri 1 Sukasada \\ e-mail: PutuSuarbawa939@gmail.com
}

\begin{abstract}
ABSTRAK
Penelitian ini bertujuan meningkatkan hasil belajar mata pelajaran Corell Draw siswa kelas $X$ DKV SMK Negeri 1 Sukasada tahun pelajaran 2018/2019 dengan penerapan model pembelajaran Problem Based Learning (PBL). Jenis penelitian ini adalah Penelitian Tindakan Kelas (PTK). Penelitian dilaksanakan sebanyak 2 siklus. Subyek penelitian adalah siswa kelas X DKV SMK Negeri 1 Sukasada tahun pelajaran 2018/2019 yang berjumlah 28 orang. Data dianalisis menggunakan kuantitaif dan kualitatif. Berdasarkan hasil penelitian didapatkan Terjadi peningkatan hasil belajar Corel Draw pada siklus I dengan rata-rata sebesar 74,29 yang termasuk ke dalam kategori kurang, dengan sedangkan ketuntasan klasikal sebesar 53,57 \%. Sedangkan pada siklus II rata-rata Corel Draw siswa sebesar 88,75 yang termasuk klasifikasi baik, dengan daya dan ketuntasan klasikal sebesar $100 \%$ dari 28 siswa. Dari analisis data di atas model pembelajaran Problem Based Learning (PBL) terbukti efektif dalam meningkatkan hasil belajar Corell Draw siswa.
\end{abstract}

Kata Kunci : Hasil belajar Corell Draw, model pembelajaran Problem Based Learning (PBL).

\begin{abstract}
This study aims to improve the learning outcomes of Corell Draw subjects in $\mathrm{X}$ graade DKV SMK Negeri 1 Sukasada in 2018/2019 academic year by applying the Problem Based Learning (PBL) learning model. This type of research is Class Action Research (CAR). The study was conducted in 2 cycles. The research subjects were $X$ grade students of DKV Vocational High School 1 Sukasada in 2018/2019 academic year totaling 28 people. Data were analyzed using quantitative and qualitative. Based on the results of the study, there was an increase in Corell Draw learning outcomes in the first cycle with an average of 74.29 which included in the fewer categories, while the classical completeness was $53.57 \%$. While in the second cycle, the Corell Draw average of students was 88.75 which included a good classification, with classical strength and completeness of $100 \%$ of 28 students. From the data analysis above the Problem Based Learning (PBL) learning model proved effective in improving students' Corell Draw learning outcomes.
\end{abstract}

Keywords: Corell Draw learning outcomes, Problem Based Learning (PBL) learning models 


\section{Pendahuluan}

Pendidikan adalah unsur penting dalam kehidupan. Dimana pendidikan merupakan jenjang seseorang menuntut ilmu baik dalam lingkungan rumah, lingkungan sosial maupun lingkungan sekolah. Pendidikan juga memiliki arti dimana manusia akan melakukan usaha untuk membina kepribadiannya sesuai dengan adat-istiadat, kebudayaan dan nilai-nilai yang ada di dalam masyarakat. Seiring dengan perkembangan zaman pendidikan atau paedagogie diartikan sebagai bimbingan atau pertolongan yang di berikan oleh orang yang lebih dewasa. Pendidikan dapat diartikan sebagai usaha dimana yang dijalankan seseorang agar mencapai kedewasaan mental (Hasbullah, 2012). Pendidikan juga merupakan salah satu aspek yang sangat penting untuk membentuk generasi yang siap mengganti tongkat estafet generasi tua dalam rangka membangun masa depan. Karena itu pendidikan berperan mensialisasikan kemampuan baru kepada mereka agar mampu mengantisipasi tuntutan masyarakat yang dinamis (Tas'Adi ,2014).

Di era globalisasi ini perkembangan ilmu pengetahuan dan teknologi sangatlah pesat. Teknologi sangat berperan penting dalam dunia pendidikan. Tekonologi menjadi item penting dalam kehidupan, sama halnya dengan pendidikan. Dalam pendidikan, teknologi sangatlah dibutuhkan, baik itu untuk mencari solusi permasalahan maupun mencari informasi terkait dengan pendidikan.

Kegiatan belajar didalam keseluruhan proses pendidikan di sekolah merupakan kegiatan yang paling pokok. Belajar aktif sebagai proses menciptakan hubungan antara sesuatu (pengetahuan) yang sudah di pahami dan sesuatu (pengetahuan) yang baru. Pembelajaran berlangsung sebagai suatu proses saling mempengaruhi antara guru dan siswa. Tujuan pendidikan di sekolah harus mampu mendukung kompetensi tamatan sekolah, yaitu pengetahuan, nilai, sikap, dan kemampuan siswa untuk dapat mendekatkan dirinya dengan lingkungan alam, sosial, dan kebutuhan daerah (Hariyanto, 2012).

Salah satu usaha pemerintah dalam mengembangkan mutu pendidikan yang berorientasi dengan dunia kerja adalah pengadaan Sekolah Menengah Kejuruan (SMK). Sekolah ini memberikan kemampuan atau skill sesuai dengan jurusan dimana dalam SMK lebih bersifat praktek dibandingkan teori. Hal ini bertujuan untuk membentuk skill dari siswa sehingga siswa mampu, terampil, dan diterima di dunia kerja setelah lulus dari SMK. Kemampuan ini tentu saja tidak didapatkan dalam pendidikan SMA. Salah satu karakteristik tamatan SMK adalah harus memiliki kompetensi untuk melaksanakan pekerjaan tertentu, dapat mengembangkan dirinya di dunia kerja, dan memiliki kecakapan untuk menjalani kehidupannya secara baik.

Berdasarkan hasil pengamatan yang telah dilakukan oleh peneliti, hasil belajar pada mata pembelajaran Corell draw yang diperoleh pada saat observasi pada siswa kelas X DKV SMK Negeri 1 Sukasada ditemukan beberapa masalah rendahnya hasil belajar pada mata pembelajaran Corell draw tergolong kedalam kategori sangat kurang jika di bandingkan kedalam kretiria ketuntasan minimal (KKM) yakni $80 \%$. Selain itu juga siswa merasa bosan karena siswa pada umumnya hanya menerima informasi yang diberikan oleh guru. Siswa lebih cenedrung mendengarkan, menulis atau mencatat dan memprakekkan apa yang diperintahkan oleh guru.

Munculnya masalah-masalah di kelas X DKV SMK Negeri 1 Sukasada tersebut pada dasarnya disebabkan oleh proses pembelajaran yang belum optimal hasil observasi di dapatkan atau ditemukan banyak guru DKV masih memberikan atau melaksanakan pembelajaran yang bersifat konvensional masih berpusat pada guru (teacher centred). Proses pembelajaran seperti ini tidak memberikan kesempatan bagi siswa untuk berkreativitas dalam memecahkan masalah yang mereka hadapi sehari-hari. Hal inilah yang menyebabkan pembelajar menjadi kurang bermakna bagi siswa.

Dalam proses pembelajaran masih berpusat pada guru (teacher centred) yang menjadi faktor rendahnya hasil belajar siswa. Semua hal tersebut berdampak pada siswa, yang ditandai dengan kurang adanya ketertarikan dari siswa dalam menerima pelajaran khususnya pada mata pembelajaran Corell draw, siswa belum sepenuhnya bisa menerapkan materi sehingga hasil belajar siswa kurang maksimal. Model pembelajaran yang bisa 
digunakan untuk menciptakan pembelajaran yang efektif dan menyenangkan banyak, salah satunya adalah dengan menggunakan model pembelajaran Problem Based Learning (PBL) atau pembelajaran berbasis masalah (Saehana ,2015).

Dalam pembelajaran, ada berbagai macam pendekatan yang dapat digunakan antara lain pendekatan konsep, pendekatan kontruktivistik, pendekatan kooperatif atau Cooperative Learning, pendekatan kontekstual atau Contextual Teaching and Learning (CTL), pendekatan pembelajaran berbasis masalah atau Problem Based Learning (PBL) dan sebagainya. Dari berbagai banyak pendekatan di atas, maka ada pendekatan serta metode yang sesuai untuk memecahakan masalah pembelajaran Corell draw yaitu pendekatan pembelajaran berbasis masalah atau problem based learning (PBL) dengan metode diskusi. Problem based learning merupakan pembelajaran yang menyajikan masalah-masalah tertentu yang bersifat kontekstual kepada siswa untuk kemudian dipecahkan oleh siswa. Pembelajaran ini dapat melatih kemampaun dan keterampilan siswa dalam memecahkan suatu masalah dengan mendiskusikan suatu permasalahan yang di alami lalu mendiskusikannya kedalam kelompok yang sudah ditenkukan sebelumnya.

Berbagai penelitian mengenai Problem Based Learning PBL telah dilakukan, seperti penelitian oleh Sadlo (2014) dan Rahayu dkk. (2016). Selain itu, penerapan model PBL dengan bantuan media juga telah banyak dilakukan dalam beberapa penelitian seperti penelitian Wicaksono dan Haryudo (2016), Santoso dkk. (2016), Hikmayanti dkk. (2016), Ridhowati dkk. (2016). Supanti. (2014) menyatakan bahwa penerapan Model PBL dengan media visualisasi dapat meningkatkan kemampuan berpikir kritis peserta didik pada pelajaran IPS. Demikian pula, menurut Kurniawan (2012), penerapan PBL berbantuan website secara signifikan dapat meningkatkan penguasaan konsep dan keterampilan proses sains peserta didik (Khaldun ,2016). Berdasarkan penelitian yang dilakukan oleh Festiyed dan Ernawati (2008) menyatakan bahwa pembelajaran menggunakan model problem based learning (PBL) dapat meningkatkan aktivitas dan hasil belajar siswa. Selain itu penelitian pendukung yang dilakukan oleh Saputri (2013) juga menyatakan bahwa pembelajaran berbasis masalah dapat meningkatkan hasil belajar siswa. Kegiatan siswa dalam pembelajaran tersebut diharapkan dapat berlangsung optimal manakala dilengkapi dengan metode yang dapat menunjang pembelajaran tersebut (Bektiarso,2015).

Menurut Hang dalam Sigit Mangon Wardoyo (2013:73), "metode problem based learning adalah metode pembelajaran yang menuntut siswa untuk menemukan solusi dari suatu permasalahan yang dihadapi dengan memahami kebutuhan-kebutuhan mendasar sebagai bekal menyelesaikan masalah yang ada". Jadi PBL adalah suatu metode pembelajaran dengan berbasis masalah. Masalah yang disajikan adalah masalah yang mempunyai konteks dengan dunia nyata. Menurut Hosnan (2013:325), langkah-langkah metode PBL adalah, 1) mengorientasi peserta didik, 2) mengorganisasikan peserta didik untuk belajar, 3)membimbing penyelidikan individual/kelompok, 4) mengembangkan dan menyajikan hasil karya, 5) menganalisis dan mengevaluasi proses pemecahan masalah (Surya ,2016).

Pendekatan Problem Based Learning ini sesuai untuk mata pelajaran Corell draw, tetapi implementasi pendekatan ini jarang digunakan oleh guru dalam kegiatan belajar mengajar. Hal ini disebabkan karena problem based learning memerlukan keterampilan guru untuk menyajikan masalah yang bersifat kontekstual untuk selanjutnya digunakan sebagai bahan dalam mempelajari suatu materi. Masalah yang terjadi adalah sulitnya untuk mencari masalah yang bersifat kontekstual yang dapat mengarahkan pembelajaran ruang lingkup pada suatu materi tertentu. Masalah lain pelaksanaan problem based learning dalam ruang lingkup adalah menuntut kemampuan siswa untuk berfikir tingkat tinggi mengenai permasalahan yang dihadapinya dalam permasalahan pembelajaran.

Untuk dapat mencapai kemampuan berfikir tersebut, guru harus mendesain pembelajaran sedemikianrupa sehingga siswa dapat melakukan proses pemecahan dengan baik sehingga pembelajaran akan benar-benar bermakna bagi siswa. Selain pendekatan dalam proses belajar mengajar, metode mengajar juga perlu dipertimbangkan keefektifannya sehingga dapat memberikan proses dan hasil yang baik dalam kegiatan belajar mengajar di kelas. 
Berdasarkan kondisi peserta didik, guru, fasilitas, dan proses pembelajaran Corel Draw di kelas X DKV SMK Negeri 1 Sukasada, serta memperhatikan keunggulankeunggulan yang dimiliki model pembelajaran Problem Based Learning (PBL), maka melalui Penelitian Tindakan Kelas (PTK) ini peneliti akan mencoba menerapkan model pembelajaran tersebut dalam pembelajaran Multimedia di kelas X DKV SMK Negeri 1 Sukasada dengan harapan dapat meningkatkan hasil belajar siswa.

Berdasarkan uraian di atas, maka peneliti akan mencoba melakukan penelitian dengan judul "Penerapan Model Problem Based Learning (PBL) Pada Mata Pembelajaran Corel Draw Untuk Meningkatkan hasil belajar di Ranah Psikomotor.

\section{Metode}

Tempat Penelitian ini termasuk ke dalam Penelitian Tindakan Kelas (PTK). PTK bertujuan untuk mewujudkan proses penelitian yang mempunyai manfaat ganda baik bagi peneliti yang dalam hak ini mereka memperoleh informasi yang berkaitan dengan permasalahan, maupun pihak subjek yang diteliti dalam mendapatkan manfaat langsung dari adanya tindakan nyata (Darmadi, 2011: 246).

Jenis penelitian yang digunakan oleh peneliti ialah menggunakan penelitian tindakan kelas (PTK) atau dikenal dengan istilah classroom action research. Dalam penelitian kolaboratif, pihak yang melakukan tindakan kelas adalah guru itu sendiri, sedangkan yang diminta melakukan pengamatan terhadap berlangsungnya proses tindakan adalah peneliti (Arikunto, 2012). PTK adalah proses pengkajian masalah pembelajaran di dalam kelas melalui refleksi diri dan upaya untuk memecahkannya dengan cara melakukan berbagai tindakan yang terencana dalam situasi nyata serta menganalisis setiap pengaruh dari tindakan tersebut (Sanjaya, 2014).

Dalam penelitian tindakan kelas ini dilaksanakan sebanyak dua siklus dengan masingmasing siklus terdiri dari dua kali pertemuan. Masing-masing siklus terdiri dari empat tahapan, yaitu: (1) Rencana tindakan, (2) Pelaksanaan tindakan, (3) observasi/evaluasi, dan (4) reflekasi. Pelaksanaan PTK dapat dilihat pada gambar 01. sebagai berikut. Agar lebih jelas, dapat di lihat pada gambar di bawah ini. 


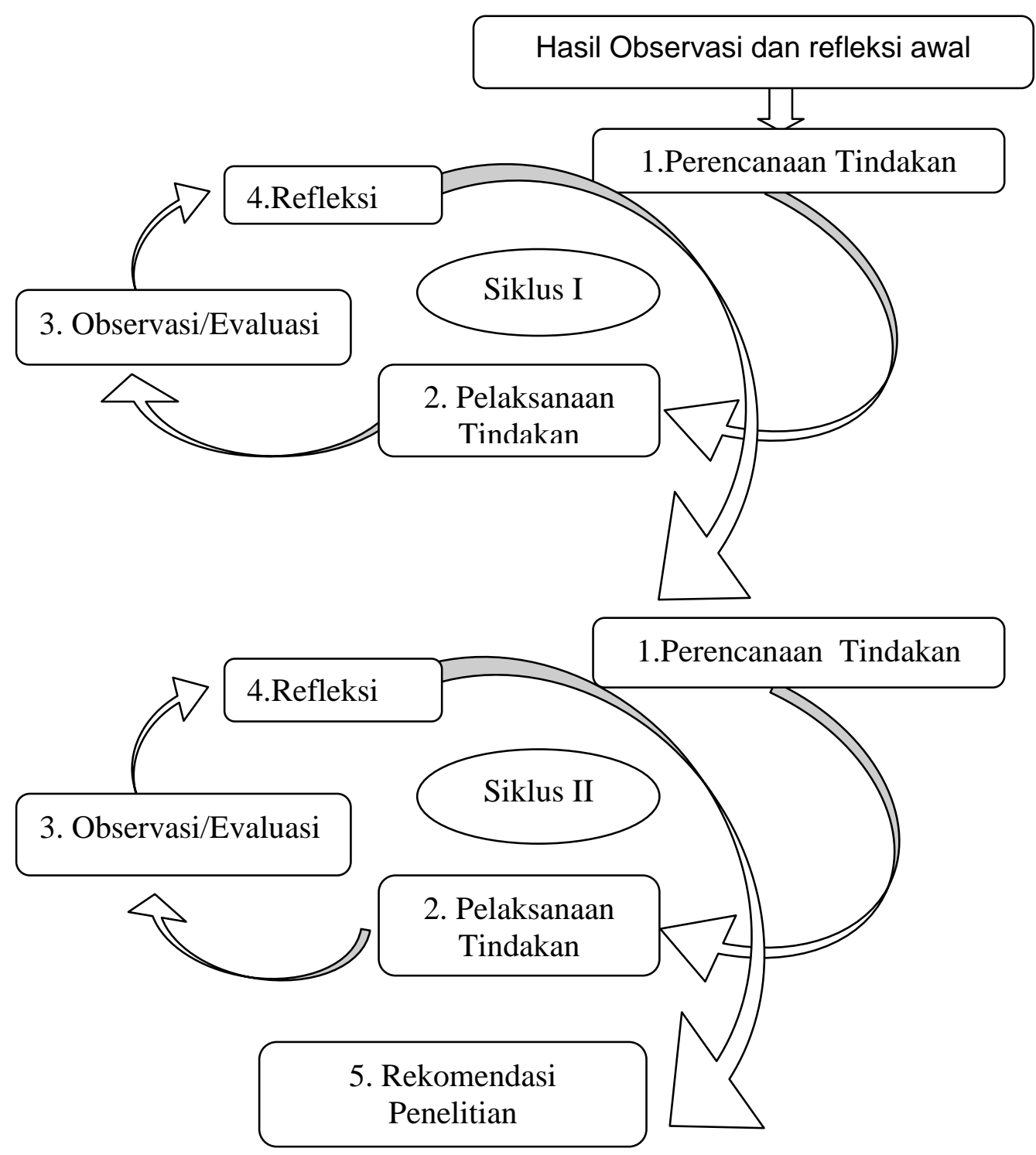

(Kanca, I Nyoman, 2010:139).

Gambar 1. Pelaksanaan Penelitian Tindakan Kelas

Subyek dalam penelitian ini adalah siswa kelas X DKV SMK Negeri 1 Sukasada, dengan jumlah 28 orang siswa perempuannya 14 dan laki laki nya 14 orang. Dan yang menjadi Objek penelitian tindakan kelas ini adalah hasil belajar Corel Draw pada mata pelajaran Multimedia.

Metode pengumpulan data yang digunakan dalam penelitian ini yaitu berupa Tes. Tes dan lembar pengamatan psikomotor siswa. Adapun materi yang dijadikan poin di dalam PTK ini adalah Corel Draw pada mata pelajaran Multimedia. Data yang dikumpulkan dalam penelitian ini dianalisis dengan menggunakan analisis kuantitatif dan kualitatif. Data hasil belajar Corel Draw siswa dianalisis secara deskriptif berdasarkan skor rata-rata $(\bar{X})$.

Rumus yang digunakan untuk mengukur skor kemampuan matematika adalah:

$$
\bar{X}=\frac{\sum X}{N}
$$

(Arikunto, 2016) 
Keterangan:

$$
\begin{array}{ll}
\bar{X} & =\text { rata-rata kelas } \\
\sum_{\mathrm{N}} X & =\text { jumlah skor yang dicapai seluruh siswa } \\
& =\text { banyak siswa }
\end{array}
$$

Ketuntasan aspek kognitif siswa dapat di tentukan dengan menggunakan daya serap siswa (DSS) dan ketuntasan klasikal (KK).

$$
\mathrm{KK}=\frac{\text { Banyak siswa yang tuntas }}{\text { banyak siswa yang ikut tes }} \mathrm{X} 100 \%
$$

Untuk memenuhi kriteria tersebut maka skor data yang diperoleh harus dikonversi ke skala 100 dengan rumus seperti berikut ini.

$$
\text { Nilai }=\frac{\text { Skor yang diperoleh siswa }}{\text { Skor maksimum }} \times 100
$$

Pedoman penggolongan hasil belajar Corell Draw pada mata pelajaran Multimedia siswa terhadap penerapan model pembelajaran Problem Based Learning (PBL) dinyatakan dengan Tabel 2 berikut.

Tabel 2. Pedoman Penggolongan kemampuan Corel Draw Siswa Pada Mata Pelajaran Multimedia

\begin{tabular}{cc}
\hline Persentase Skor Total siswa & Katagori Kemampuan siswa \\
\hline $94-100$ & Sangat Baik \\
$87-93$ & Baik \\
$80-86$ & Cukup \\
$73-79$ & Kurang Baik \\
$0-72$ & Sangat Kurang Baik \\
\hline & (Sumber : KTSP SMK Negeri 1 Sukasada)
\end{tabular}

Penelitian Tindakan Kelas ini dikatakan berhasil jika terjadi peningkatan hasil belajar Corel Draw pada mata pelajaran Multimedia siswa sesuai dengan target yang ditetapkan. Target keberhasilan penelitian ini adalah siswa mampu mencapai skor rerata yaitu minimal 80 , dan ketuntasan klasikal minimum $80 \%$.

\section{Hasil dan Pembahasan}

Hasil belajar pada siklus I dengan materi Corell Draw, diperoleh data hasil belajar dengan kategori individu sebagai berikut: tidak ada siswa yang mendapat nilai dengan kategori sangat baik (A), 4 orang (14,3\%) memperoleh nilai dengan kategori baik (B), 11 orang (39,3\%) memperoleh nilai dengan kategori cukup (C),dan 4 orang (14,3\%) memperoleh nilai dengan kategori sangat kurang. Dari data hasil belajar siswa pada siklus I maka siswa yang tuntas sebanyak 15 orang $(53,57 \%)$ dan siswa yang tidak tuntas sebanyak 13 orang $(46,43 \%)$.Dengan ketercapainya hasil belajar siswa tersebut maka penelitian ini akan dilanjutkan ke siklus II dengan melihat kekurangan dan hambatan pada siklus I pada siklus II dengan materi Corell Draw, diperoleh data hasil belajar dengan kategori individu sebagai berikut: mendapat nilai dengan kategori nilai sangat baik (A) 8 orang siswa $(28,6 \%), 6$ orang $(21,4 \%)$ memperoleh nilai dengan kategori nilai baik (B), 14 orang $(50 \%)$ memperoleh nilai dengan kategori nilai cukup $(\mathrm{C})$ tidak ada siswa yang mendapat nilai cukup 
(D), nilai kurang tidak ada (0\%). dan tidak ada siswa yang mendapat nilai sangat kurang (E) $(0 \%)$. Dari data hasil belajar pada siklus II maka siswa yang tuntas sebanyak 28 orang $(100 \%)$ atau semuanya tuntas

Persentase ketuntasan hasil belajar Corell Draw secara klasikal pada siklus I adalah $74,29 \%$ dan persentase ketuntasan belajar Corell Draw secara klasikal pada siklus II adalah 85,7\%. Peningkatan ketuntasan hasil belajar Corell Draw dari siklus I ke siklus II adalah $11,41 \%$.

Peningkatan ini tidak terlepas dari penerapan model pembelajaran kooperatif tipe PBL secara optimal dengan perbaikan-perbaikan pembelajaran sesuai dengan kekurangankekurangan, hambatan dan kendala-kendala yang terjadi pada setiap siklus sebelumnya. Dari peningkatan hasil belajar Corell Draw merupakan bukti dari penerapan model pembelajaran kooperatif tipe PBL (Problem Based Learning) ini, siswa mendapat kesempatan yang luas untuk melatih keterampilan dan juga memberi waktu yang luas untuk belajar gerak baik secara individu maupun secara kelompok, suasana belajar siswa selama kegiatan pembelajaran nampak bebas, ceria, bergairah, dan kondusif. Disamping itu siswa dapat berkolaborasi dengan teman kelompoknya. Siswa belajar dan beraktivitas sendiri untuk memperoleh pengalaman, pengetahuan, pemahaman, dan tingkah laku lainnya serta mengembangkan keterampilannya yang bermakna serta mengembangkan keterampilan yang bermakna di mana siswa sudah mulai sangat aktif dan antusias selama proses pembelajaran, mampu bekerja sama dengan teman dan memahami materi pelajaran dengan sangat baik khususnya materi Corell Draw. Sehingga dalam hal ini, kegiatan atau gaya belajar siswa merupakan pondasi untuk mencapai hasil belajar yang lebih optimal. Keberhasilan dalam penelitian sesuai dengan teori-teori yang mendukung dalam proses pembelajaran.

"Belajar adalah suatu proses yang melibatkan manusia secara orang per orang sebagai satu kesatuan organisasi sehingga terjadi perubahan pada pengetahuan, keterampilan dan sikapnya" (Dimyati dan Mudjiono, 2006:116). "Hasil belajar merupakan suatu puncak proses belajar, hasil belajar tersebut meningkat terjadi terutama berkat evaluasi guru, dan juga merupakan hasil dari suatu interaksi tindak belajar dan tindak mengajar" (Dimyati dan Mudjiono, 2006:3).

Selain itu penelitian ini dikuatkan oleh beberapa hasil peneliti sebelumnya yang menggunakan model pembelajaran kooperatif tipe PBL (Problem Based Learning) untuk mengatasi masalah pembelajaran yang terpusat pada guru yang berakibat siswa pasif dalam pembelajaran. Beberapa peneliti terdahulu menemukan peningkatkan hasil belajar siswa melalui model pembelajan tipe PBL (Problem Based Learning) adalah: (1) penelitian yang

dilakukan oleh Inten Dwi Payani, A.A Istri (2012:99) yang menemukan adanya peningkatan terhadap hasil belajar mata pelajaran prakarya dan kewirausahaan penerapan model pembelajaran kooperatif tipe PBL (Problem Based Learning).Penelitian yang dilaksanakan ini, tidaklah selalu berjalan dengan lancar sesuai dengan yang diharapkan dan yang sudah direncanakan. Karena ada kendala-kendala yang dihadapi peneliti dalam menjalankan penelitian ini. Adapun kendala-kendala yang dihadapi yaitu: (1) fasilitas yang dimiliki sekolah masih kurang, alat-alat yang ada seperti Led, Komputer sekolah belum maksimal dalam memfasilitasi ke seluruh siswa, (2) respon siswa untuk memahami materi tergolong lambat.

Dari kendala-kendala yang dihadapi tersebut maka yang dilakukan peneliti untuk memecahkannya sehingga penelitian yang dilakukan dapat berjalan dengan lancar diantaranya yaitu: (1) menggunakan sarana yang ada dan meminjam laptop ke guru-guru agar penelitian ini berjalan lancar dan kondusif. (2) menjelaskan kembali secara berulangulang materi yang belum dimengerti agar siswa lebih memahami materi yang dipelajari.

Berdasarkan hasil penelitian yang telah dilakukan peneliti serta teori-teori pendukung hasil penelitian yang dipaparkan, maka dapat disimpulkan bahwa penerapan model pembelajaran tipe PBL (Problem Based Learning) dapat meningkatkan hasil belajar Corell Draw pada siswa kelas X DKV SMK Negeri 1 Sukasada Semester Genap tahun pelajaran 2017/2018. Untuk itu disarankan kepada guru DKV (Desain Komunikasi Visual), untuk 
berupaya menerapkan pembelajaran tipe PBL (Problem Based Learning) dalam proses pembelajaran sebagai salah satu alternatif untuk meningkatkan hasil belajar Corell Draw.

\section{Simpulan dan Saran}

Hasil belajar Corell Draw pada siswa kelas X DKV SMK Negeri 1 Sukasada Semester Genap tahun pelajaran 2017/2018 Semester Ganjil tahun pelajaran 2017/2018. Hal ini dapat dilihat dari persentase ketuntasan hasil belajar Corell Draw pada siklus I sebesar 13 orang $(46,43 \%)$ kategori tuntas dan Siklus II sebesar 28 orang (100\%) sudah semua tuntas. Dan dilihat dilihat dari persentase rata-rata ketuntasan hasil belajar siswa secara klasikal untuk hasil belajar Corell Draw mengalami peningkatan sebesar $13,21 \%$ dari $74,29 \%$ pada siklus I yang tergolong pada kategori kurang baik menjadi $87,5 \%$ pada siklus II yang tergolong pada kategori baik.

\section{Daftar Pustaka}

Adiputra, I. N. (2014). Pengembangan E-Modul pada Materi "Melakukan Instalasi Sistem Operasi Jaringan Berbasis GUI dan Text" untuk Siswa Kelas X Teknik Komputer dan Jaringan SMK Negeri 3 Singaraja. Januari 20, 2015, from Karmapati Pendidikan Teknik Informatika, Universitas Pendidikan Ganesha.

Amiroh. (2012). Membangun E-Learning dengan Learning Management System Moodle. Sidoarjo: PT Berkah Mandiri Globallindo.

Ananda, M. (2014). Pengembangan E-Learning Berbasis Schoology Pada Mata Pelajaran IPA Kelas VIII di SMP Negeri 1 Seririt. Jurusan Teknologi Pendidikan. Journal Edutech Universitas Pendidikan Ganesha.

Bektiarso ,Singgih (2015). Penerapan Model Problem Based Learning (Pbl) Disertai Metode Pictorial Riddle Dalam Pembelajaran Fisika Di Sma . Jurnal Pembelajaran Fisika, Vol.4 No.3, Desember 2015, hal 261 - 267.

BSNP. 2007. Peraturan Menteri Pendidikan Nasional Republik Indonesia Nomor 41 Tentang Standar Proses Untuk Satuan Pendidikan Dasar Dan Menengah. Jakarta: Badan Standar Nasional Pendidikan.

Candiasa, I. M. (2010). Pengujian Instrumen Penelitian Disertasi ITEMAN dan BIGSTEP. Singaraja: Universitas Pendidikan Ganesha.

Depdiknas. 2006. Kurikulum Tingkat Satuan Pendidikan. Jakarta : Departemen Pendidikan Nasional

Depdiknas. 2008a. Panduan Pengembangan Bahan Ajar. Dirjen Dikdasmen Direktorat Pembinaan SMA.

Depdiknas. 2008b. Teknik Penyusunan Modul. Dirjen Dikdasmen Direktorat Pembinaan SMK.

Dewi, N. K., Garminah, N. N., \& Pudjawan, K. (2013). Pengaruh Model Pembelajaran Berbasis Proyek (Project- Based Learning) Terhadap Hasil Belajar IPA Siswa Kelas IV SD N 8 Banyuning. Retrieved Januari 20, 2015, from http://download.portalgaruda.org/article. php?article=105329\&val=1342.

Dimyati dan Mudjiono. 2006. Belajar dan Pembelajaran. Jakarta: Rineka Cipta.

2010. Penelitian Tindakan kelas (Classroom action Research). Makalah. Disajikan dalam Pelatihan PTK Guru Penjasorkes se-Bali, Jumat, 12 Desember 2008. 
Erlin Frida Siregar. 2011. Penerapan model pembelajaran kooperatif tipe student teams Achievement division (stad) untuk meningkatkan hasil belajar Ips siswa kelas iv di sd negeri 78 sebangar kecamatan mandau Kabupaten bengkalis. Universitas Riau. Tersedia pada: http:// repository.unri.ac.id/.../1/ .JURNAL\%20ERLIN.pdf (diakses tanggal 8 November 2013)

Hamalik, Oemar. 2001. Proses Belajar Mengajar. Jakarta: Bumi Aksara.

Hanum, N. S. (2013). Keefektifan E-learning Sebagai Media Pembelajaran (Studi Evaluasi Model Pembelajaran E-learning SMK Telkom Sandhy Putra Purwokerto). Jurnal Pendidikan Vokasi, Vol 3, Nomor 1, Februari 2013

Heri Setiawan, Putu. 2011. Implemantasi Model Pembelajaran Kooperatif Tipe Student Teams Achievement Division (STAD) Untuk Meningkatkan Aktivitas dan Hasil Belajar Passing Bola Basket pada Siswa Kelas VIII D SMP N 2 Singaraja Tahun Pelajaran 2010/2011. Singaraja: Jurusan Pendidikan Jasmani Kesehatan dan Rekreasi, Fakultas Olahraga dan Kesehatan, Universitas Pendidikan Ganesha.

Ibrahim, dkk. 2000. Pembelajaran Kooperatif. Surabaya: Universitas Negeri Surabaya.

Khaldun ,Ibnu (2016). Penerapan Model Pembelajaran Problem Based Learning (Pbl) Dengan Media Audio Visual Pada Materi Ikatan Kimia Terhadap Penguasaan Konsep Dan Berpikir Kritis Peserta Didik Sma Negeri 1 Panga . Jurnal Pendidikan Sains Indonesia, Vol. 04, No.02, hlm 96-105, 2016

Nurkancana dan Sunartana. 1992. Evaluasi Hasil Belajar. Surabaya : Usaha Nasional.

Pawana, M. G. (2014). Pengembangan Multimedia Interaktif Berbasis Proyek Dengan Model Addie Pada Materi Pemrograman Web Siswa Kelas X Semester Genap di SMK Negeri 3 Singaraja. e-Journal Program Pascasarjana Universitas Pendidikan Ganesha, 1-10.

Peraturan Pemerintah Nomor 74 Tahun 2008 Tentang Guru. 2008. Tersedia : http://datahukum.pnri.go.id/index.php?option=com phocadownload\&view=category\& download=2771:pp74tahun2008\&id=28:tahun-2008\&ltemid=28\&start=80 (12 Agustus 2013)

Ratumanan, Tanwey Gerson. 2002. Belajar dan Pembelajaran. Surabaya: Unesa University Press.

Saehana ,Sahrul (2015). Pengaruh Model Problem Based Learning Menggunakan Simulasi Terhadap Hasil Belajar Siswa Pada Materi Gerak Lurus Kelas VII MTs Bou . Jurnal Pendidikan Fisika Tadulako (JPFT) Vol. 3 No. 3 ISSN 23383240

Satria Adi Utama, I Komang. 2011. Implemantasi Model Pembelajaran Kooperatif Tipe Student Teams Achievement Division (STAD) Untuk Meningkatkan Aktivitas dan Hasil Belajar Tolak Peluru pada Siswa Kelas VIII A1 SMP N 1 Sawan Tahun Pelajaran 2010/2011. Singaraja: Jurusan Pendidikan Jasmani Kesehatan dan Rekreasi, Fakultas Olahraga dan Kesehatan, Universitas Pendidikan Ganesha.

Santyasa dan Sukadi. 2007. Model-Model Pembelajaran Inovatif. Singaraja : Undiksha.

Sudjana, Nana. 2006. Penilaian Hasil Proses Belajar Mengajar. Bandung: Remaja Rosdakarya. 
Suprijono, Agus. 2009. Cooperative Learning. Yogyakarta : Pustaka Pelajar.

Suroto, dkk. 2007.Pembelajaran Penjasorkes Inovatif untuk Pendidikan dasar. Surabaya : Balitbang-Pulitjaknov.

Slavin, Robert. E. 2010. Cooperative Learnig. Bandung: Nusa Media.

Syarifuddin, Aip. 1997. Pendidikan Jasmani dan Kesehatan 1 SLTP Kelas 1. Jakarta: PT. Grasindo.

Sugiyanto, dkk. 1998. Perkembangan dan Belajar Motorik. Jakarta: Departemen Pendidikan dan Kebudayaan. Direktorat Jenderal Pendidikan Dasar dan Menengah Bagian Proyek Peningkatan Mutu Guru Pendidikan Jasmani dan Kesehatan SD Setara D-II.

Surya ,Ariz (2016). Penggunaan Metode Problem Based Learning (Pbl) Berbantuan Media Audio Visual Untuk Meningkatkan Hasil Belajar Matematika Siswa Sekolah Dasar . Jurnal Pendidikan Dasar, Volume 4, Nomor 2

Tas' Adi ,Rafsel (2014). Pentingnya Etika Dalam Pendidikan . Jurnal Bimbingan Konseling STAIN Batusangkar Volume 17, No. 2 Desember 2014

Tegeh, I. M. (2013). Pengembangan Bahan Ajar Metode Penelitian Pendidikan dengan Addie Model. Jurnal IKA, 12-26.

Tegeh, I. M., \& Kirna, I. M. (2010). Metode Penelitian Pengembangan Pendidikan. Singaraja: Undiksha.

Thobroni, M \& Arif,M. 2011. Belajar dan Pembelajaran. Yogyakarta : AR-RUZZ MEDIA.

Trianto. 2007. Model-model Pembelajaran Inovatif Berorientasi kostruktivistik. Jakarta: Prestasi Pustaka Puhlisner.

Wijayanti, N. P. (2016). pengembangan e-modul berbasis project based learning pada matapelajaran simulasi digital untuk siswa kelas X di SMK Negeri 2 Singaraja. jurnal pendidikan teknologi dan kejuruan.

Winaya, I. K. (2016). Pengwmbangan E-Modul Berbasis Project Based Learning Pada Matapelajaran Pemrograman Web Kelas X Di Smk Negeri 3 Singaraja. Jurnal Pendidikan teknologi dan kejuruan.

Wiyoko, T. (2014). Pengembangan Media Pembelajaran Fisika Modul Elektronik Animasi Interaktif Untuk Kelas XI SMA Ditinjau Dari Motivasi Belajar Siswa. Jurnal Pendidikan Fisika, 11-15. 